\title{
Demand-Supply Balance Analysis of Agricultural Organic Waste Recycling in Northern Henan Province, China
}

\author{
Qingsheng Zhou ${ }^{1 *}$, Xinzheng Li², Chunlin Yang1, Yufei Zhao ${ }^{1}$ \\ ${ }^{1}$ School of Resource and Environment, Henan Institute of Science and Technology, Xinxiang, China \\ ${ }^{2}$ School of Horticulture and Landscape Architecture, Henan Institute of Science and Technology, Xinxiang, China
}

Received: 17 July 2017

Accepted: 6 November 2017

\begin{abstract}
For more efficient utilization of agricultural organic waste composts, this research formulates the demand of agricultural organic waste composts and the supply of compost converted from agricultural organic waste in the region, and models the demand-supply balance of agricultural organic waste compost in some regions. Objects of study include 6 urban districts, 5 county-level cities, and 21 counties in northern Henan Province, China. The crops' latent demand for compost and the latent supply of compost converted from agricultural organic wastes (straw and livestock manure) in each region is computed for an analysis of demand-supply balance. According to the findings, there is a large deviation in both the ratio of the supply of livestock manure composts to that of straw composts and the demand-supply ratio of composts in the studied regions. To be specific, the overall demand-supply ratio in the studied regions is about 1.21, showing that demand is greater than supply. Theoretically, all agricultural organic wastes can be used for agricultural production in these regions. In addition, actual demand ratio (actual demand/ latent demand) is found in the utilization of composts. Supposing the actual demand ratio is $50 \%$, research again analyzes the demand-supply balance, revealing that all livestock manure composts can be utilized, but that straw compost is surplus in large amounts in the studied regions.
\end{abstract}

Keywords: northern Henan Province, compost, latent demand, latent supply, demand-supply ratio

\section{Introduction}

In recent years, attention has been paid to the development of circular agriculture. An important countermeasure for the development of circular agriculture is to recover the land of agricultural organic wastes [1-3]. Efficient utilization of agricultural organic

*e-mail: 249306303@qq.com wastes is constantly stressed, but they are not so efficiently utilized in many areas [4]. Henan Province's annual output of agricultural organic wastes includes straw and livestock manure coming first throughout China [5-6]. For example, its annual output of various livestock manures is more than 130 million tons, approx. 31 million tons after being dried; and there are more than 130 registered compost production enterprises in the whole province and their annual production capacity is approx. 1.8 million tons, but safely fermented manure is no more than 500,000 tons [7]. Based on the 


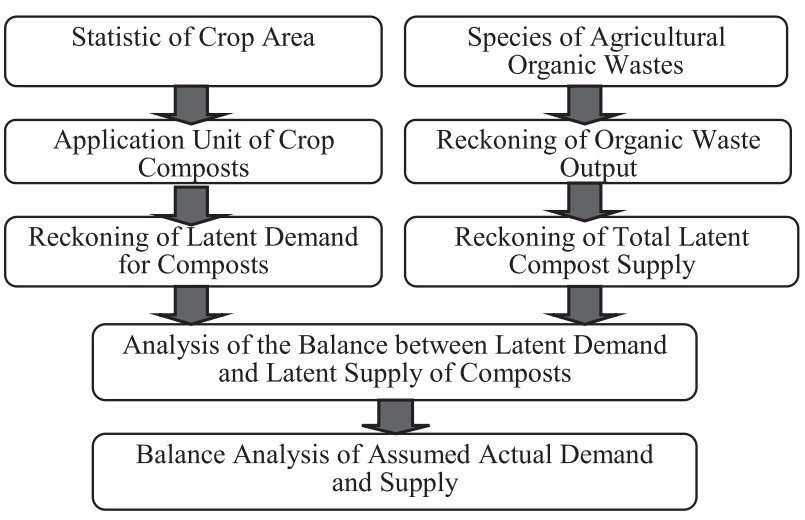

Fig. 1. Analysis process of the demand-supply balance of agricultural organic waste.

above data, it can be reckoned that these enterprises' production capacity accounts for $6 \%$ of total occurrence quantity, and their actual production output is about $1.6 \%$ of total occurrence quantity. However, the rate of livestock manure has reached $97 \%$ in Japan as computed by the Ministry of the Environment (the state of garbage classification, occurrence, and disposal in Japan) [8-9]. For the past few years, China has reached a world-class level in terms of research on composting technology and agricultural organic waste pollution treatment [1012]. Now that the application of agricultural organic waste composts requires a large amount of labor and is affected by movement limit and regional coverage [13], a probability analysis of the demand and supply of agricultural organic waste composts in some regions is a scientific means to enhance their efficient utilization [14]. Nevertheless, there is no research in a region wider than Henan Province. For this reason, it is of great importance to analyze the demand-supply balance of agricultural organic waste composts and to study countermeasures for their utilization.

This research takes regions to the north of the Yellow River in Henan Province (hereinafter referred to as northern Henan Province) as objects of study and assumes that agricultural organic wastes including straws and livestock manures in these regions are utilized. These regions are chosen for the following reasons:

- Regional limitations in the recycling application of agricultural organic waste compost; the studied regions are separated by the Yellow River from other regions in Henan Province, so they have better intraregional movement efficiency of agricultural organic waste composts.
- Agricultural organic wastes in these regions, as resources like those in other regions of Henan Province, are not fully utilized; besides, related research on the demand-supply balance of agricultural organic waste composts in the studied regions is lacking.

- The studied regions, developed in planting and breeding industries, have sufficient demand and supply of agricultural organic waste compost.

\section{Material and Methods}

\section{Study Area}

Northern Henan Province has about 20.3723 million citizens (19.11\% of Henan Province's total population) and a cultivated area of approx. $18,600 \mathrm{~km}^{2}$, or $22.71 \%$ of Henan Province's total cultivated area. Enjoying a warm temperate continental monsoon climate and an average temperature of $13-14.5^{\circ} \mathrm{C}$, the area has four distinctive seasons: dry spring, hot summer, cool autumn, and cold winter. Its abundant rain, fertile soil, and rich light and heat are suitable for the growth of crops and the development of the livestock industry [15]. Main livestock in northern Henan Province includes cattle, sheep, pigs and fowl, and main crops are wheat and corn. Moreover, this area has high-level output and planting technology of soybean, cotton, peanut, rapeseed, and sesame [16].

The studied regions include urban districts (a generic term of districts in a prefecture-level city), counties, and county-level cities in six prefecturelevel cities such as Xinxiang City, Jiaozuo City, Jiyuan City, Anyang City, Hebi City, and Puyang City. Jiyuan City covers a small area without county-level city and county in its administrative division, so this region is studied as a whole. The studied regions consists of 6 urban districts, 5 county-level cities, and 21 counties. In this paper, crops' theoretical maximum demand for composts (hereinafter referred to as latent demand), and the occurrence quantity of agricultural organic wastes including straws and livestock manures and theoretical maximum supply of converted composts (hereinafter referred to as supply) are reckoned respectively. A quantitative analysis of the demand-supply demand of agricultural organic waste composts and their utilization probability in the studied regions is made to provide a scientific basis for the effective utilization of agricultural organic wastes in these regions. The specific research process is shown in Fig. 1.

Table 1. Original fertilization unit of crops (wet basis; $t / h a$ ).

\begin{tabular}{|c|c|c|c|c|c|c|c|c|}
\hline $\begin{array}{c}\text { Crop } \\
\text { species }\end{array}$ & $\begin{array}{c}\text { Summer } \\
\text { crops }\end{array}$ & $\begin{array}{c}\text { Autumn } \\
\text { CROPS }\end{array}$ & Oil crops & Fruit trees & Vegetables & Cotton & $\begin{array}{c}\text { Chinese } \\
\text { herbs }\end{array}$ & Others \\
\hline $\begin{array}{c}\text { Application } \\
\text { Unit }\end{array}$ & 10 & 10 & 15 & 20 & 20 & 15 & 20 & 20 \\
\hline
\end{tabular}




\begin{tabular}{|c|c|c|c|c|c|c|c|c|c|c|c|c|c|c|c|c|c|}
\hline \multirow{2}{*}{ 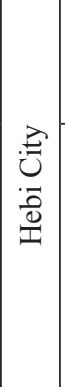 } & 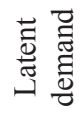 & $\stackrel{\vartheta}{\overrightarrow{\bar{v}}}$ & $\stackrel{m}{\stackrel{i}{\dot{i}}}$ & $\begin{array}{l}\tilde{n} \\
\varrho \\
0\end{array}$ & $\stackrel{n}{\stackrel{n}{r}}$ & 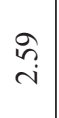 & $\begin{array}{c}0 \\
⿱ 亠 䒑 \\
\dot{y} \\
y\end{array}$ & $\begin{array}{l}\stackrel{n}{\mathfrak{d}} \\
\stackrel{\Xi}{\Xi}\end{array}$ & & & & & & & & & \\
\hline & 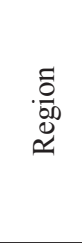 & 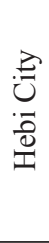 & 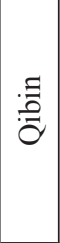 & 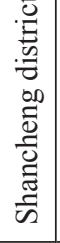 & 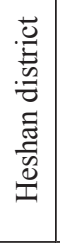 & 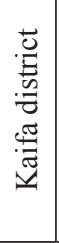 & 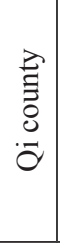 & 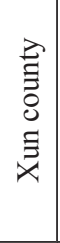 & & & & & & & & & \\
\hline \multirow[b]{2}{*}{ 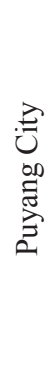 } & 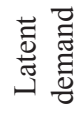 & $\begin{array}{l}\infty \\
n_{n} \\
\text { in }\end{array}$ & $\begin{array}{l}\curvearrowright \\
\infty \\
\dot{\Xi} \\
-\end{array}$ & $\begin{array}{l}\infty \\
\stackrel{\sim}{\vartheta} \\
\stackrel{J}{-}\end{array}$ & $\begin{array}{l}\hat{\sigma} \\
\hat{\sigma}\end{array}$ & $\begin{array}{l}n \\
\hat{\sigma}\end{array}$ & $\begin{array}{l}\overrightarrow{\widehat{c}} \\
\dot{q}\end{array}$ & $\begin{array}{l}\vec{F} \\
\stackrel{g}{a}\end{array}$ & $\stackrel{m}{\hat{\sigma}}$ & & & & & & & & \\
\hline & 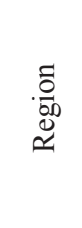 & 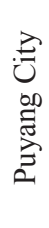 & 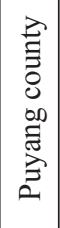 & 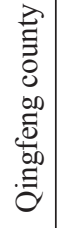 & 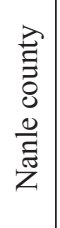 & 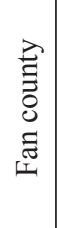 & 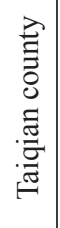 & 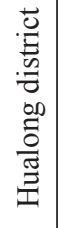 & 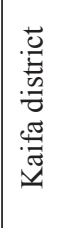 & & & & & & & & \\
\hline \multirow[b]{2}{*}{ 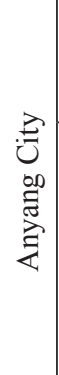 } & 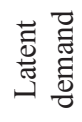 & 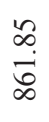 & $\begin{array}{c}n \\
\cdots \\
a\end{array}$ & $\begin{array}{l}q \\
\text { qu }\end{array}$ & $\begin{array}{l}\tilde{i} \\
i n\end{array}$ & $\begin{array}{l}\overrightarrow{0} \\
\end{array}$ & $\begin{array}{l}\stackrel{\infty}{\infty} \\
\stackrel{a}{a} \\
\end{array}$ & $\begin{array}{l}\infty \\
\dot{0} \\
\dot{\alpha}\end{array}$ & $\stackrel{\substack{n \\
=}}{=}$ & 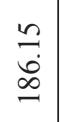 & $\begin{array}{l}\hat{\beta} \\
\dot{\sigma}\end{array}$ & & & & & & \\
\hline & 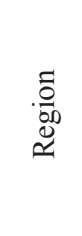 & 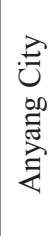 & 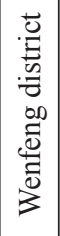 & 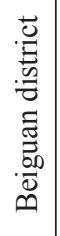 & 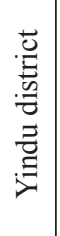 & 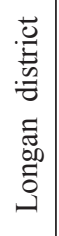 & 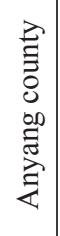 & 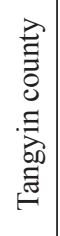 & 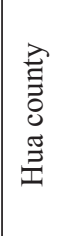 & 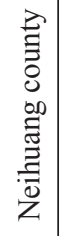 & 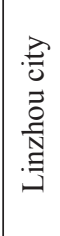 & & & & & & \\
\hline \multirow[b]{2}{*}{ 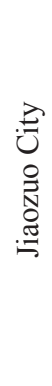 } & 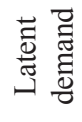 & \begin{tabular}{r}
\multirow{2}{*}{} \\
$\stackrel{n}{\tilde{m}}$
\end{tabular} & $\begin{array}{l}0 \\
\stackrel{0}{0}\end{array}$ & $\begin{array}{l}\vec{r} \\
\dot{r}\end{array}$ & $\underset{\infty}{\hat{\infty}}$ & $\stackrel{\infty}{\stackrel{\infty}{n}}$ & $\overrightarrow{\dot{r}}$ & $\begin{array}{l}\stackrel{B}{\dot{+}} \\
\dot{F}\end{array}$ & $\begin{array}{l}\infty \\
\infty \\
i \\
i\end{array}$ & 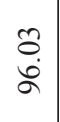 & $\underset{\overrightarrow{1}}{\vec{i}}$ & $\begin{array}{l} \pm \\
0 \\
0 \\
0\end{array}$ & $\begin{array}{l}\hat{m} \\
\hat{n}\end{array}$ & & & & \\
\hline & $\begin{array}{l}\text {.0 } \\
.00 \\
\simeq \\
\simeq\end{array}$ & 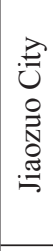 & 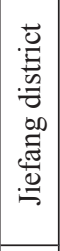 & 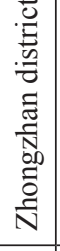 & 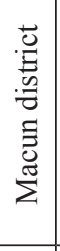 & 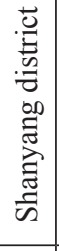 & 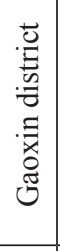 & 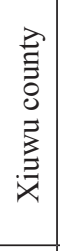 & 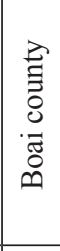 & 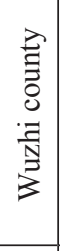 & 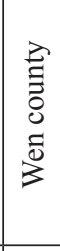 & 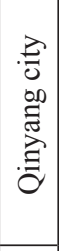 & 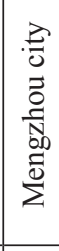 & & & & \\
\hline \multirow[b]{2}{*}{ 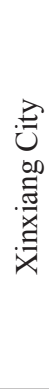 } & 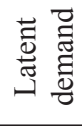 & 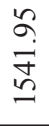 & $\begin{array}{l}\infty \\
0 \\
\dot{ \pm} \\
\end{array}$ & $\begin{array}{c}0 \\
\infty \\
\infty\end{array}$ & 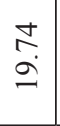 & $\begin{array}{l}\infty \\
\stackrel{丶}{r}\end{array}$ & $\begin{array}{l}\hat{n} \\
n \\
n\end{array}$ & $\begin{array}{l}\stackrel{P}{+} \\
\dot{+}\end{array}$ & 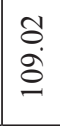 & 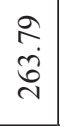 & $\begin{array}{l}\stackrel{2}{\circ} \\
\stackrel{+}{2}\end{array}$ & $\begin{array}{l}\infty \\
\stackrel{o}{+} \\
\stackrel{+}{+} \\
\end{array}$ & $\begin{array}{l}\Re \\
\infty \\
\sim \\
\sim \\
\sim\end{array}$ & $\begin{array}{l}q \\
\stackrel{9}{0} \\
\stackrel{0}{0} \\
-\end{array}$ & $\stackrel{m}{\underset{\sim}{ \pm}}$ & & \\
\hline & $\begin{array}{l}\tilde{0} \\
\stackrel{0}{60} \\
\stackrel{0}{\simeq}\end{array}$ & 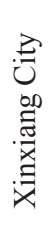 & 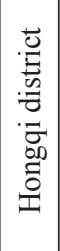 & 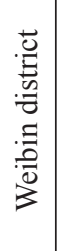 & 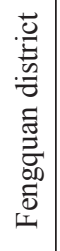 & 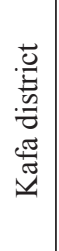 & 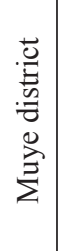 & 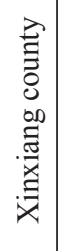 & 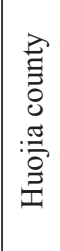 & 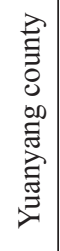 & 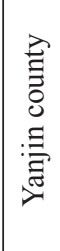 & 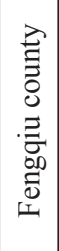 & 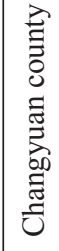 & 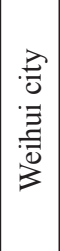 & 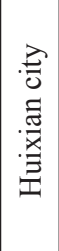 & & \\
\hline \multirow[b]{2}{*}{ 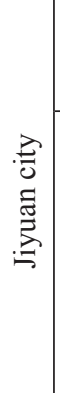 } & 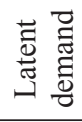 & $\begin{array}{l}\text { mे } \\
\text { in } \\
\text { n. }\end{array}$ & 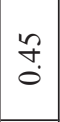 & $\stackrel{\vartheta}{0}$ & $\stackrel{\overbrace{}}{-}$ & $\underset{\sim}{\stackrel{\infty}{\sim}}$ & $\begin{array}{l}\hat{\sigma} \\
\dot{ \pm}\end{array}$ & $\stackrel{\stackrel{尺}{\Xi}}{=}$ & $\begin{array}{l}\tilde{I} \\
\dot{f}\end{array}$ & $\begin{array}{l}\infty \\
\infty \\
\bigcirc\end{array}$ & $\begin{array}{l}\infty \\
\infty \\
0 \\
0\end{array}$ & ले & $\begin{array}{l}\mathbb{t} \\
\text { i } \\
\text { in }\end{array}$ & $\begin{array}{l}\infty \\
\stackrel{\infty}{\sim}\end{array}$ & 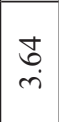 & $\stackrel{\hat{n}}{\mathfrak{I}}$ & $\stackrel{\infty}{=}$ \\
\hline & 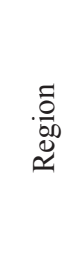 & $\begin{array}{l}\text { 总 } \\
\text { 罢 } \\
\text { 蛋 }\end{array}$ & 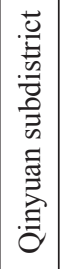 & 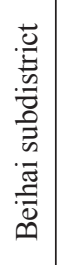 & 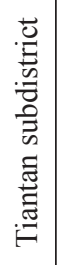 & 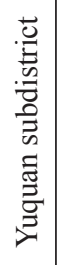 & 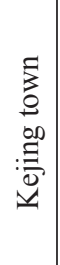 & $\begin{array}{l}\bar{z} \\
0 \\
\overline{0} \\
\overline{0} \\
\frac{0}{80} \\
\overline{0} \\
\frac{0}{3}\end{array}$ & 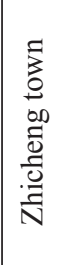 & 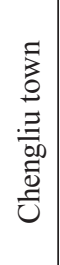 & 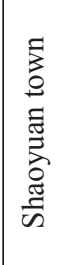 & $\begin{array}{l}\tilde{z} \\
0 \\
0 \\
0 \\
0 \\
0 \\
0\end{array}$ & 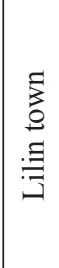 & 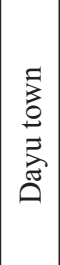 & 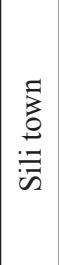 & 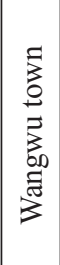 & 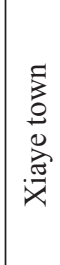 \\
\hline
\end{tabular}


Methods

\section{Reckoning of Talent Compost Demand}

Crops' latent demand for composts is calculated on the basis of the cultivated area of crops and the application standards (hereinafter referred to as original fertilization unit) of crop composts. This research uses Formula (1) to calculate the latent demand for composts in the studied regions:

$$
D_{i}=A_{i} B_{n}
$$

...where:

$D_{i}$ : latent demand for composts (t/year)

$A$ : cultivated area of crops (ha)

$B$ : original fertilization unit of crops $(\mathrm{t} / \mathrm{ha})$

$n$ : crops

$i$ : regions

The cultivated area of various crops $A$ in the studied regions is obtained from The Statistical Yearbook of Henan Province [17]. Different crops have different demand for composts (see literature data [18] for the original fertilization unit of crops $B$, as shown in Table 1.). According to Formula (1), the original fertilization unit, and the cultivated area of crops, the latent demand for composts in the studies regions is calculated, with results shown in Table 2. The annual latent demand for composts in the studied regions is approx. 37.57 million tons. Since Jiyuan City has the smallest crop area among the six prefecture-level cities, it has the lowest annual latent demand for compost, at approx. 1.5539 tons. Xinxiang City has the highest latent demand for compost through the whole year, at approx. 15.4195 million tons, accounting for $40 \%$ of northern Henan Province's total demands. Due to its biggest latent demand for compost, Xinxiang is the center of demand for compost in northern Henan Province.

\section{Reckoning of Latent Supply of Livestock Manure Compost}

The number of various livestock in each region $T_{i j}$ multiplies by the daily occurrence quantity of various livestock manures $S_{j}$ (hereinafter referred as original unit) and then multiplies by the raising days in a year to get the annual occurrence quantity of various fresh livestock manures. Now that fresh manures need to be made into composts in accordance with national standards by fermenting and drying, the weight will be reduced after fresh manure is converted into compost. This paper defines the ratio of the weight of composts to the weight of fresh manures as composting rate. Different livestock's fresh manures have different water content, so the composting rate of different livestock manures differs. The annual occurrence quantity of various fresh livestock manures multiplies by the composting rate of various livestock manures $E_{j}$ to get the latent supply of livestock manure composts in the studied regions $H_{i j}$ (Formula (2)):

$$
H_{i j}=\left(T_{i j} S_{j} 365\right) E_{j}
$$

...where:

$H_{i j}$ : the latent supply of livestock manure compost (t/year)

$T_{i i j}$ : the number of livestock in the studied regions

$S_{j}^{i j}$ : the original occurrence unit of various livestock manures ( $\mathrm{kg} /$ day)

$E_{i}$ : the composting rate of livestock manure

$j$ : livestock

$i$ : regions

The number of various livestock in the studied regions is obtained from The Statistical Yearbook of Henan Province [17] (see literature data for the original occurrence unit of different livestock manures [19] and calculate the composting rate of various livestock

Table 3. Original occurrence unit and the composting rate of livestock manure.

\begin{tabular}{|c|c|c|c|c|c|c|c|}
\hline Livestock Species & Dairy Cattle & Beef Cattle & Horse, Donkey and Mule & Pig & Sheep & Rabbit & Chicken \\
\hline $\begin{array}{c}\text { Original Occurrence } \\
\text { (kg/day) }\end{array}$ & 45 & 20 & 14 & 3 & 1.7 & 0.15 & 0.14 \\
\hline Composting Rate (\%) & 40 & 40 & 40 & 40 & 60 & 60 & 60 \\
\hline Livestock Species & Dairy Cattle & Beef Cattle & Horse, Donkey and Mule & Pig & Sheep & Rabbit & Chicken \\
\hline $\begin{array}{c}\text { Original Occurrence } \\
\text { (kg/day) }\end{array}$ & 45 & 20 & 14 & 3 & 1.7 & 0.15 & 0.14 \\
\hline Composting Rate (\%) & 40 & 40 & 40 & 40 & 60 & 60 & 60 \\
\hline $\begin{array}{c}\text { Livestock Species } \\
\text { Dairy Cattle }\end{array}$ & Beef Cattle & Horse, Donkey and Mule & Pig & Sheep & Rabbit & Chicken \\
\hline $\begin{array}{c}\text { Original Occurrence } \\
\text { (kg/day) }\end{array}$ & 45 & 20 & 14 & 3 & 1.7 & 0.15 & 0.14 \\
\hline Composting Rate (\%) & 40 & 40 & 40 & 40 & 60 & 60 & 60 \\
\hline
\end{tabular}

*Composting rate: the rate of converting fresh livestock manures into compost (the weight of livestock manure compost/the weight of fresh livestock manure)*100\% 


\begin{tabular}{|c|c|c|c|c|c|c|c|c|c|c|c|c|c|c|c|c|c|}
\hline \multirow[b]{2}{*}{ 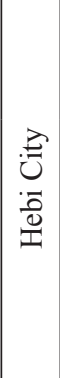 } & 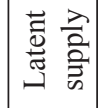 & 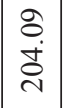 & $\begin{array}{l}\infty \\
\stackrel{\infty}{2} \\
\stackrel{2}{2}\end{array}$ & $\stackrel{\varrho}{=}$ & $\begin{array}{l}\simeq \\
\Xi \\
\pm\end{array}$ & $\begin{array}{l}\infty \\
\dot{0} \\
\dot{0}\end{array}$ & 号 & $\mid \begin{array}{l}\infty \\
n \\
0 \\
0\end{array}$ & & & & & & & & & \\
\hline & 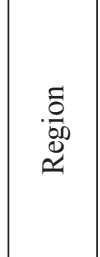 & 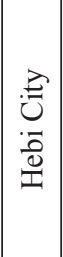 & : & 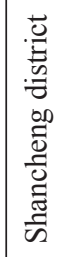 & 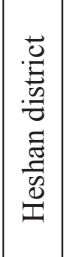 & 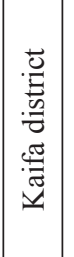 & $\mid \begin{array}{l}0 \\
0 \\
0 \\
0 \\
0 \\
0\end{array}$ & 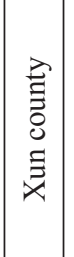 & & & & & & & & & \\
\hline \multirow{2}{*}{ 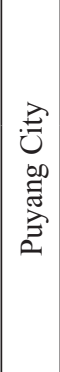 } & 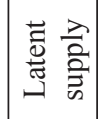 & 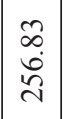 & $\begin{array}{l}n \\
\dot{0} \\
n\end{array}$ & $\stackrel{\overrightarrow{\dot{b}}}{\vec{\gamma}}$ & $\begin{array}{l}n \\
2 \\
\infty \\
\infty\end{array}$ & \begin{tabular}{|l|}
$\vec{\infty}$ \\
$\dot{\infty}$ \\
$\infty$
\end{tabular} & $\begin{array}{l}\mathfrak{a} \\
\grave{i} \\
\grave{d}\end{array}$ & ñ & $\begin{array}{l}8 \\
0\end{array}$ & & & & & & & & \\
\hline & 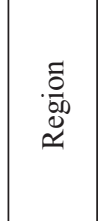 & 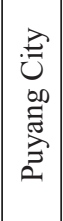 & 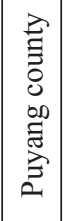 & 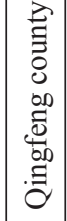 & 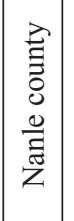 & 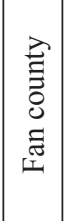 & 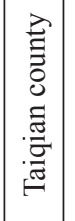 & 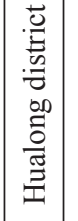 & 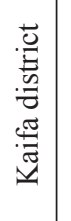 & & & & & & & & \\
\hline \multirow{2}{*}{ 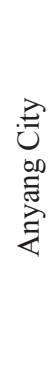 } & 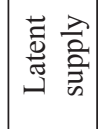 & $\begin{array}{l}n \\
0 \\
0 \\
m \\
m\end{array}$ & 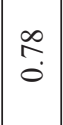 & $\frac{n}{2}$ & 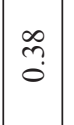 & बे & $\begin{array}{c}\overrightarrow{0} \\
\dot{\sigma} \\
\end{array}$ & $\begin{array}{l}\overrightarrow{\dot{0}} \\
\dot{m}\end{array}$ & 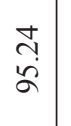 & 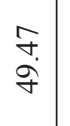 & $\begin{array}{l}\hat{B} \\
\infty \\
\infty\end{array}$ & & & & & & \\
\hline & 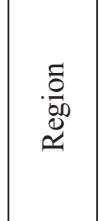 & 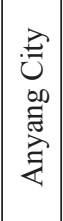 & 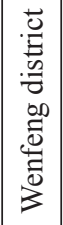 & 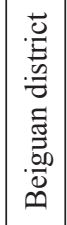 & 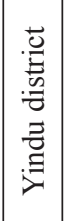 & 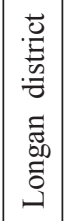 & 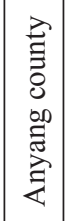 & 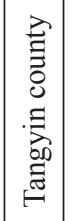 & 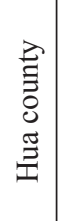 & 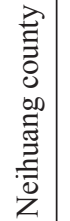 & 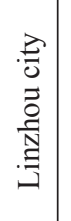 & & & & & & \\
\hline \multirow[b]{2}{*}{ 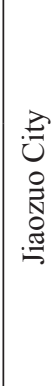 } & 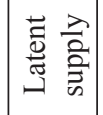 & $\begin{array}{l}\vec{t} \\
\stackrel{\vec{v}}{\mathbf{v}} \\
\end{array}$ & $\begin{array}{l}0 \\
\infty \\
0 \\
0\end{array}$ & $\stackrel{0}{\stackrel{n}{\rightarrow}}$ & $\stackrel{9}{-}$ & 导 & 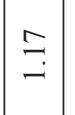 & ñ & $\begin{array}{l}\vec{\infty} \\
\dot{\phi} \\
\dot{\phi}\end{array}$ & $\stackrel{n}{\stackrel{2}{f}}$ & $\begin{array}{l} \pm \\
\dot{0} \\
\dot{D}\end{array}$ & $\begin{array}{l}0 \\
\stackrel{?}{2} \\
\grave{\lambda}\end{array}$ & $\begin{array}{l}\hat{a} \\
\tilde{j} \\
\end{array}$ & & & & \\
\hline & 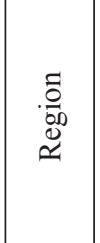 & 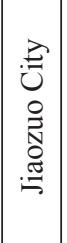 & 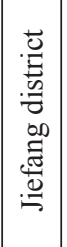 & 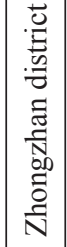 & 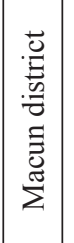 & 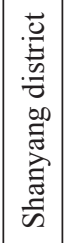 & 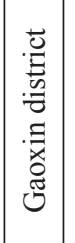 & 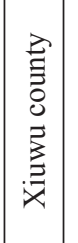 & 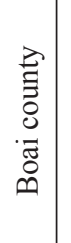 & 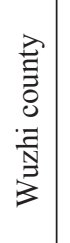 & 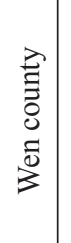 & 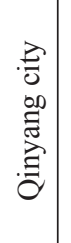 & 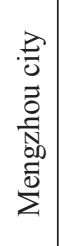 & & & & \\
\hline \multirow{2}{*}{ 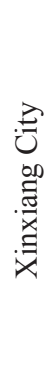 } & 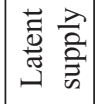 & $\mid \begin{array}{c}m \\
\tilde{b} \\
\tilde{n} \\
\end{array}$ & $\stackrel{q}{q}$ & $\stackrel{\circ}{\stackrel{2}{+}}$ & $\begin{array}{l}\hat{\sigma} \\
i \\
i\end{array}$ & $\overrightarrow{\dot{\sigma}}$ & $\stackrel{i}{i}$ & $\begin{array}{l}\tilde{n} \\
\dot{d}\end{array}$ & $\begin{array}{l}\text { 安 } \\
\text { 㟧 }\end{array}$ & $\begin{array}{l}\stackrel{ }{\infty} \\
\tilde{n}\end{array}$ & $\begin{array}{l}\tilde{N} \\
\stackrel{\lambda}{2}\end{array}$ & \begin{tabular}{c|}
8 \\
$\stackrel{0}{0}$ \\
$\stackrel{+}{+}$
\end{tabular} & $\begin{array}{l}\vec{\alpha} \\
\infty \\
\dot{m}\end{array}$ & $\mid \begin{array}{l}0 \\
\infty \\
\stackrel{R}{R}\end{array}$ & $\begin{array}{l}\dot{b} \\
\infty \\
\infty \\
\infty \\
n\end{array}$ & & \\
\hline & $\begin{array}{l}\text {. } \\
\text { 总 } \\
\approx \\
\simeq\end{array}$ & 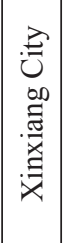 & 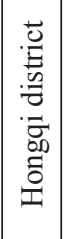 & 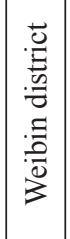 & 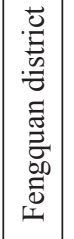 & 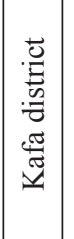 & 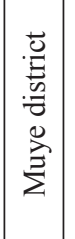 & 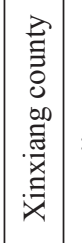 & 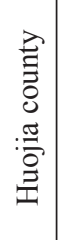 & 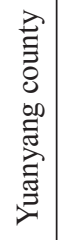 & 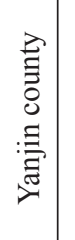 & 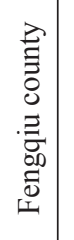 & 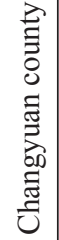 & $\mid \begin{array}{l}3 \\
0 \\
0 \\
0 \\
\frac{3}{0} \\
3 \\
3\end{array}$ & 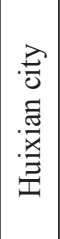 & & \\
\hline \multirow[b]{2}{*}{ 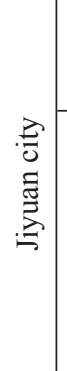 } & 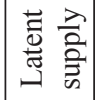 & $\frac{\infty}{0}$ & 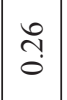 & $\begin{array}{l}\vec{R} \\
\dot{0}\end{array}$ & 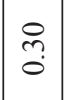 & $\widehat{\widetilde{i}}$ & 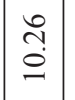 & $\stackrel{\infty}{\stackrel{\infty}{r}}$ & $\underset{I}{\stackrel{I}{I}}$ & ஃ̊ & $\stackrel{\stackrel{?}{+}}{+}$ & 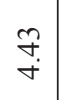 & \begin{tabular}{|l}
$\infty$ \\
\multirow{\infty}{*}{} \\
$\infty$
\end{tabular} & $\begin{array}{l}\stackrel{\infty}{\sim} \\
\tilde{m}\end{array}$ & $\begin{array}{l}0 \\
\infty \\
i\end{array}$ & $\begin{array}{l}t \\
\dot{+} \\
\dot{+}\end{array}$ & $\underset{+}{+}$ \\
\hline & 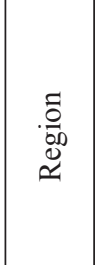 & 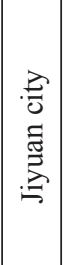 & 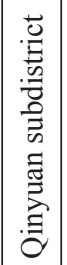 & 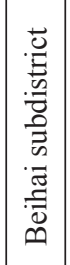 & 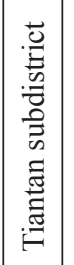 & 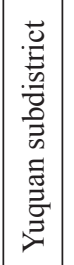 & 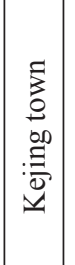 & 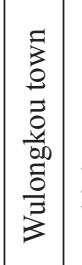 & 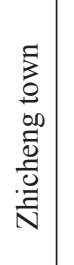 & 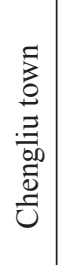 & 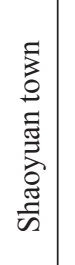 & $\begin{array}{l}\text { 咅 } \\
0 \\
0 \\
0 \\
0 \\
0 \\
0\end{array}$ & 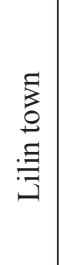 & 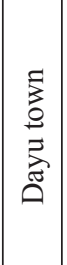 & 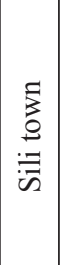 & 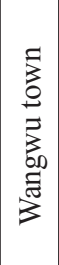 & 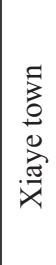 \\
\hline
\end{tabular}


Table 5. Occurrence coefficient of crop straws.

\begin{tabular}{|c|c|c|c|c|c|c|c|}
\hline \multirow{2}{*}{$\begin{array}{c}\text { Occurrence Coefficient } \\
\text { of Crop Straw }\end{array}$} & Unit & Barley, Wheat & Rice & Corn & Bean & Oil & Cotton \\
\cline { 2 - 8 } & $\mathrm{t} / \mathrm{t}$ & 1.0 & 1.0 & 1.5 & 3.0 & 2.0 & 4.0 \\
\hline
\end{tabular}

manure based on literature data [4].). Table 3 shows the original occurrence unit and the composting rate of various livestock manures.

The annual latent supply of livestock manure composts in the studied regions of northern Henan Province is calculated according to Formula (2), the number of various livestock, the original occurrence unit of fresh manure, and the composting rate, with results shown in Table 4. The annual latent supply of livestock manure composts in the studied regions is approx. 14.08 million tons. The sum of Xinxiang City and Anyang City is 6.69 million tons, about $48 \%$ of the total quantity in northern Henan Province, implying sufficient raw materials of livestock manure compost in the two regions.

\section{Reckoning of Latent Supply of Crop Straw Composts}

The latent supply of crop straw composts is calculated according to Formula (3). During the harvest season of crops, straws are basically dry and their water content meets the standard of compost, so they can fully work as compost. The harvest yield of various crops $U_{i j}$ multiplies by the occurrence coefficient of various crop straws $V_{j}$ (the occurrence quantity of straws/the harvest yield of crops) to get the latent supply of various crop straw composts $P_{i j}$ :

...where:

$$
P_{i j}=U_{i j} V_{j}
$$

$P_{i j}$ : latent supply of straw compost (t/year)

$U_{i j}^{i j}$ : harvest yield of crops ( $\mathrm{t} /$ year)

$V_{j}$ : occurrence coefficient of various straws

$j$ : crops

$i$ : regions

The harvest yield of various crops in the studied regions is obtained from The Statistical Yearbook

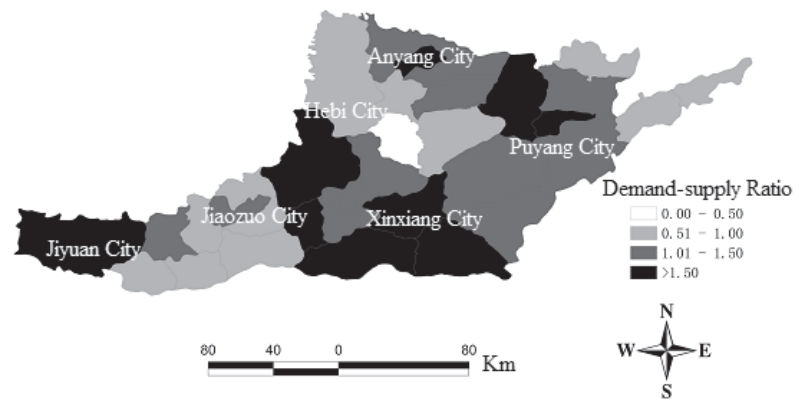

Fig. 2. Latent demand-supply ratio of agricultural organic waste compost in the studied regions of northern Henan Province. of Henan Province [17]. The occurrence coefficient of different crop straws is calculated on the basis of literature data [20] (Table 5).

The annual latent supply of straw composts in the studied regions is calculated according to Formula (3), the harvest yield of various crops and the occurrence coefficient of different crop straws, with results shown in Table 6. The annual latent supply of straw compost in the studied regions is approx. 16.91 million tons. Xinxiang and Anyang's annual latent supply of straw compost totals 8.99 million tons, or about $53 \%$ of the all supplies in northern Henan Province, revealing that the two regions have sufficient raw materials of straw compost.

\section{Results and Discussion}

\section{Analysis of Latent Demand-Supply Balance}

In the studied regions of northern Henan Province, the overall latent demand of agricultural organic waste compost is approx. 37.5738 million tons a year and the latent supply of compost is about 31.0007 million tons a year. Fig. 2 shows the demandsupply ratio (demand/supply) of compost in this area. If the ratio is above 1.0, it indicates more latent demand than latent supply. According to the data above, it can be reckoned that the overall compost demand-supply ratio in northern Henan Province is 1.21. Theoretically, if there is more demand than supply, agricultural organic wastes can be fully used for agricultural production in this area. Among the studied regions, Xinxiang City, with a developed planting industry, has a demandsupply ratio of above 1.0 in all regions and the highest overall average demand-supply ratio in northern Henan Province, at approx. 1.83. Xun County, Hebi City, with the smallest planting area, has the lowest demandsupply ratio of 0.35 . The ratio in all studied regions of Hebi is above 1.0 and the overall demand-supply ratio is about 0.59 , at the lowest level among the six prefecturelevel cities. The research reveals a big deviation in the demand-supply ratio of composts in the studied regions of northern Henan Province.

Fig. 3 lists the ratio of the latent demand of compost to the latent supply of agricultural organic waste composts in the studied regions. Regarding large-size livestock, cattle contribute $12 \%$ manure compost, and horses, donkeys, and mules about $0.1 \%$, totaling $12.1 \%$. $11 \%$ of compost is from pig manure, $4.3 \%$ from sheep manure, and $18 \%$ from chicken (hereinafter referred to as fowl). The sum of composts from various livestock manures is about $45.4 \%$ of aggregate supply, and the 


\begin{tabular}{|c|c|c|c|c|c|c|c|c|c|c|c|c|c|c|c|c|c|}
\hline & 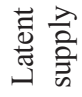 & $\begin{array}{l}\stackrel{ \pm}{\square} \\
\stackrel{n}{n}\end{array}$ & $\stackrel{\text { f }}{ \pm}$ & $\begin{array}{l}\vec{\infty} \\
\dot{i}\end{array}$ & $\stackrel{\oplus}{\oplus}$ & 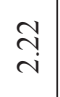 & $\underset{i}{i}$ & $\begin{array}{l}\hat{i} \\
\hat{i}\end{array}$ & & & & & & & & & \\
\hline 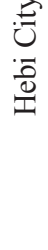 & $\begin{array}{l}\stackrel{\tilde{0}}{50} \\
\stackrel{5}{\cong}\end{array}$ & 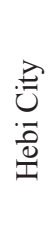 & : & 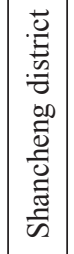 & 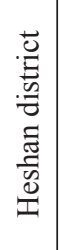 & 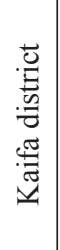 & $\begin{array}{l}\overrightarrow{3} \\
\overline{0} \\
0 \\
\ddot{0}\end{array}$ & 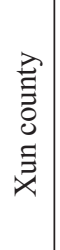 & & & & & & & & & \\
\hline \multirow{2}{*}{ 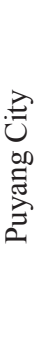 } & 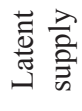 & $\begin{array}{l}n \\
\text { in } \\
\text { fr } \\
\text { men }\end{array}$ & $\begin{array}{l}\hat{0} \\
ٍ \\
=\end{array}$ & $\underset{\stackrel{ }{\mathfrak{}}}{\stackrel{2}{n}}$ & $\begin{array}{l}\hat{o} \\
\text { ì }\end{array}$ & $\begin{array}{c}\underset{\sim}{\vec{T}} \\
\underset{\mathcal{T}}{\mid}\end{array}$ & $\begin{array}{l}\stackrel{n}{+} \\
\stackrel{+}{d}\end{array}$ & $\stackrel{?}{r}$ & $\mid \begin{array}{l}\tilde{N} \\
\stackrel{n}{ \pm} \\
\end{array}$ & & & & & & & & \\
\hline & 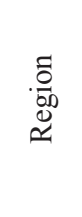 & 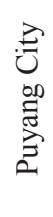 & 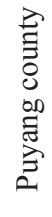 & 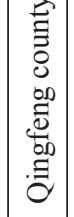 & 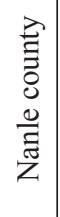 & 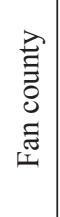 & 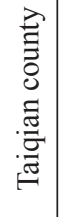 & 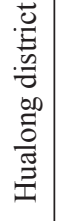 & 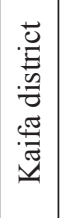 & & & & & & & & \\
\hline \multirow[b]{2}{*}{ 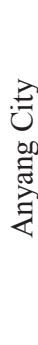 } & 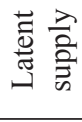 & $\begin{array}{l}\vec{F} \\
\stackrel{\odot}{\sigma}\end{array}$ & $\begin{array}{l}8 \\
\dot{m}\end{array}$ & $\stackrel{\infty}{\vec{i}}$ & $\stackrel{m}{m}$ & $\begin{array}{l}\vec{b} \\
\dot{0}\end{array}$ & 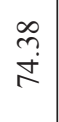 & 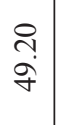 & $\begin{array}{l}0 \\
\stackrel{0}{\Xi} \\
\stackrel{\Xi}{\Xi}\end{array}$ & ते & $\begin{array}{l}\vec{\infty} \\
\vec{m}\end{array}$ & & & & & & \\
\hline & 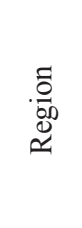 & 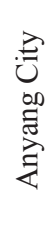 & 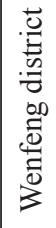 & 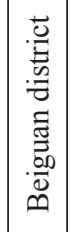 & 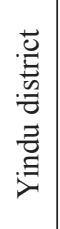 & 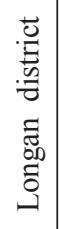 & 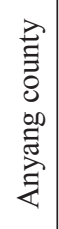 & 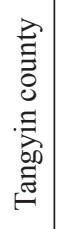 & 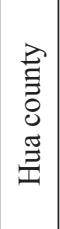 & 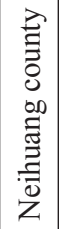 & 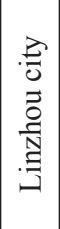 & & & & & & \\
\hline \multirow[b]{2}{*}{ 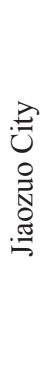 } & 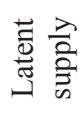 & 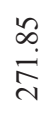 & $\hat{n}$ & $\vec{\unlhd}$ & $\underset{\stackrel{\mathcal{f}}{+}}{+}$ & $\begin{array}{l}\mathbb{U} \\
0 \\
0\end{array}$ & $\stackrel{\infty}{\stackrel{\infty}{\leftrightarrows}}$ & $\begin{array}{l}\stackrel{0}{2} \\
\stackrel{\iota}{\oplus}\end{array}$ & $\begin{array}{l}0 \\
i \\
i \\
i\end{array}$ & $\begin{array}{l}n \\
\hat{8} \\
0\end{array}$ & $\underset{d}{ \pm}$ & $\begin{array}{l}\hat{a} \\
\infty \\
\infty\end{array}$ & $\frac{\mathfrak{Z}}{\mathfrak{d}}$ & & & & \\
\hline & $\begin{array}{l}\stackrel{\tilde{0}}{50} \\
\stackrel{0}{0}\end{array}$ & 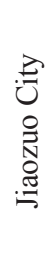 & 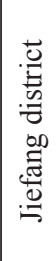 & 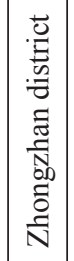 & 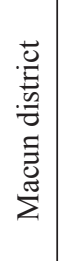 & 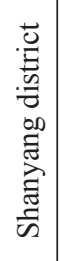 & 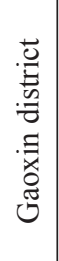 & 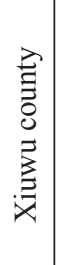 & 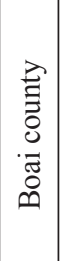 & 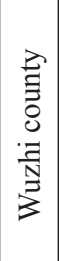 & 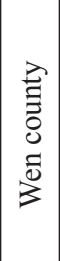 & 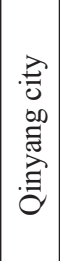 & 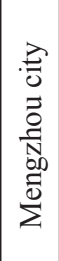 & & & & \\
\hline \multirow{2}{*}{ 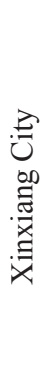 } & 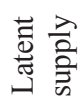 & $\begin{array}{l}\stackrel{\text { I }}{\infty} \\
\infty \\
\stackrel{\infty}{\infty}\end{array}$ & $\begin{array}{l}\stackrel{2}{\infty} \\
+ \\
+\end{array}$ & $\hat{i}$ & $\begin{array}{l}\tilde{\delta} \\
\dot{\delta} \\
\dot{r}\end{array}$ & 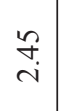 & 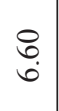 & $\stackrel{\stackrel{\circ}{\leftrightarrow}}{\stackrel{m}{2}}$ & 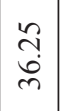 & $\underset{\mathbb{N}}{\stackrel{N}{\dot{D}}}$ & $\begin{array}{l}\mathbb{N} \\
\infty \\
\infty \\
n\end{array}$ & $\underset{\hat{i}}{\stackrel{i}{i}}$ & 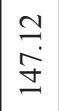 & $\begin{array}{l}\infty \\
\stackrel{\infty}{\sim} \\
\mathcal{f}\end{array}$ & $\begin{array}{l}+ \\
\dot{b} \\
\dot{b}\end{array}$ & & \\
\hline & 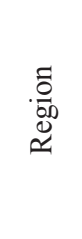 & 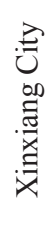 & 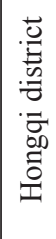 & 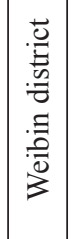 & 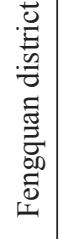 & 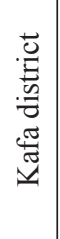 & 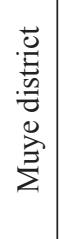 & 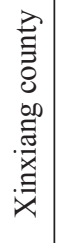 & 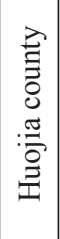 & 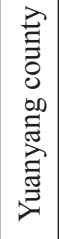 & 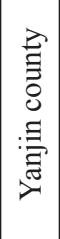 & 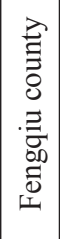 & 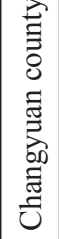 & 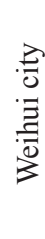 & 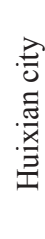 & & \\
\hline \multirow[b]{2}{*}{ 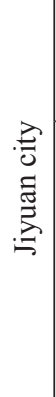 } & 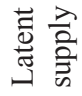 & 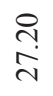 & ?ై & $\stackrel{n}{\mathfrak{c}}$ & 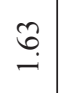 & $\tilde{n}$ & 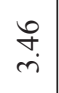 & $\vec{i}$ & $\underset{\dot{\sigma}}{\stackrel{\partial}{2}}$ & $\begin{array}{l}n \\
\tilde{r} \\
i\end{array}$ & กิ & $\stackrel{\overbrace{}}{\text { \ุ }}$ & 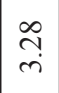 & $\exists$ & 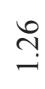 & $\begin{array}{l}\vec{\infty} \\
0 \\
0\end{array}$ & $\stackrel{?}{0}$ \\
\hline & 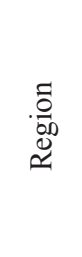 & 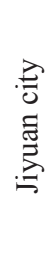 & 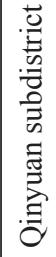 & 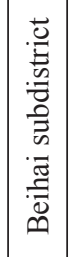 & 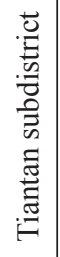 & 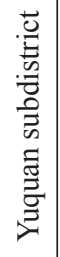 & 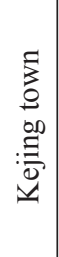 & 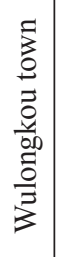 & 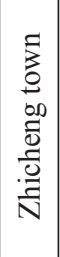 & 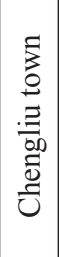 & 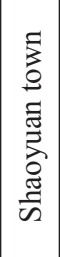 & $\mid \begin{array}{l}\tilde{z} \\
0 \\
0 \\
z \\
0 \\
0 \\
2\end{array}$ & 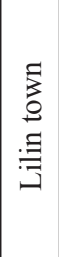 & 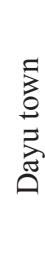 & 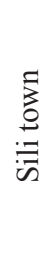 & $\begin{array}{l}\text { है } \\
0 \\
0 \\
5 \\
0 \\
\text { है } \\
3\end{array}$ & 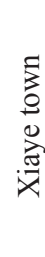 \\
\hline
\end{tabular}




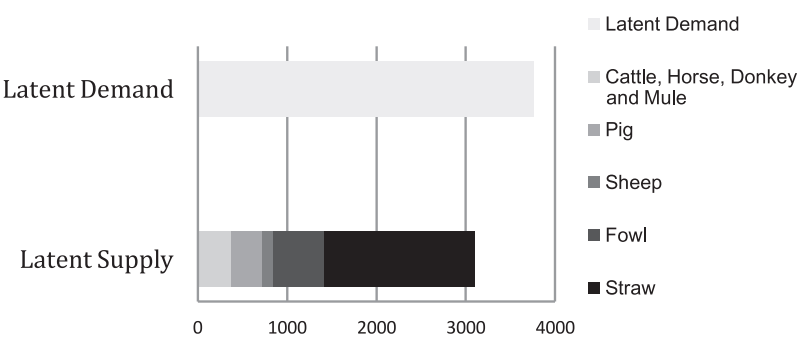

Fig. 3. Ratio of latent demand to latent supply of agricultural organic waste compost in northern Henan Province $(10,000$ tons/year $)$.

compost from straws accounts for approx. $54.6 \%$.

Fig. 4 shows the ratio of the latent supply of livestock manure compost to that of straw compost in the 6 prefecture-level cities of northern Henan Province. Among the 6 cities, Xinxiang has the largest latent supply of livestock manure and straw compost, and Jiyuan has the smallest. According to the ratio of the latent supply of livestock manure compost to that of straw compost, Jiyuan and Hebi have more livestock manure compost than straw compost. Developed feeding industry but small crop planting area are the reasons why Hebi's demand-supply ratio is only 0.59 . Jiyuan has a demand-supply ratio of 1.61. Notwithstanding small crop planting area, its wide vegetable cultivation area contributes to a great demand for compost. The other four prefecture-level cities have less latent supply of livestock manure compost than that of straw compost. Findings show that there is also a big deviation in the ratio of latent supply of livestock manure compost to that of straw compost in the studied regions of northern Henan Province.

\section{Analysis of Demand-Supply Balance when Actual Demand Rate Reaches 50\%}

The above-noted results reveal that the demand of agricultural organic waste compost falls short of supply in the studied regions of northern Henan Province. Nevertheless, the province's crops are fertilized with chemical fertilizers in actual fertilizer utilization of agricultural production. The average use intensity of

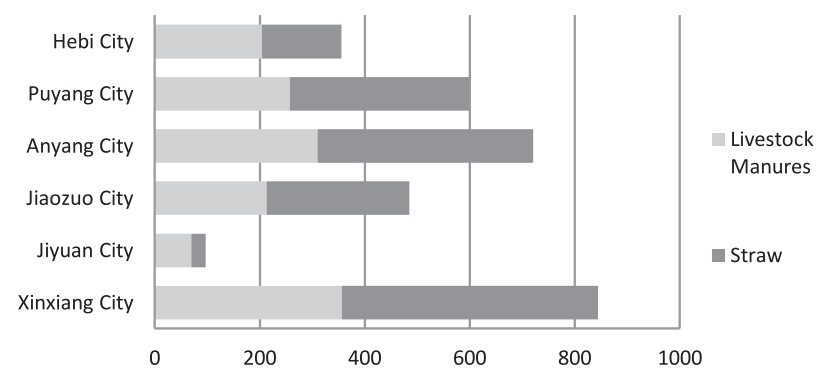

Fig. 4. Ratio of latent supply of livestock manure compost to that of straw compost in the 6 prefecture-level cities of northern Henan Province (10,000 tons/year).

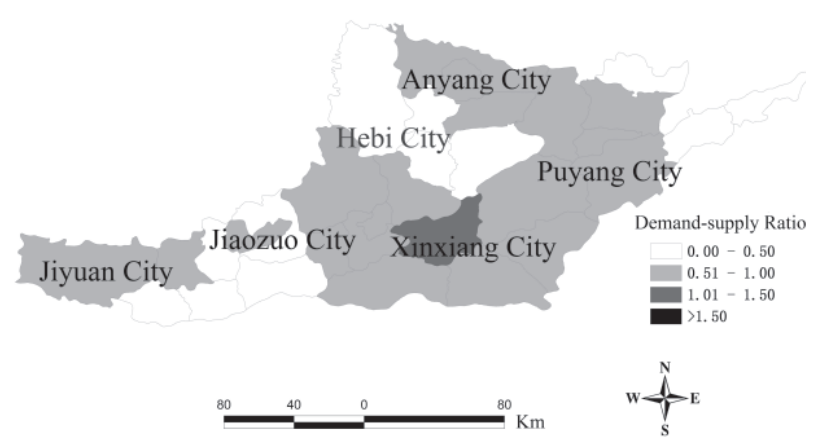

Fig. 5. Demand-supply ratio when actual compost demand rate reaches 50\% in the studied regions of northern Henan Province

chemical fertilizer in the 6 prefecture-level cities of northern Henan Province is 1.9 times as much as China's average level, and 3 times developed countries' standard [18], severely exceeding the limit. In view of this, it is difficult to use compost for all crop production in the studied regions. Moreover, using compost of equal effect with chemical fertilizers requires several times and even dozens of times the labors and transportation costs compared with chemical fertilizer, which is another region why chemical fertilizers are increasingly used year by year in this area. Considering the actual demand rate in practical application of agricultural organic waste composts (actual demand/latent demand), this research assumes the actual demand rate to be $50 \%$ and then analyzes the demand-supply balance of composts in corresponding condition. The demand-supply ratio when the actual demand rate is $50 \%$ in the studied regions of northern Henan Province is shown in Fig. 5.

As shown in Fig. 5, among the 6 urban districts, 5 county-level cities and 21 countries in the studied regions, only Yanjin County, Xinxiang City has a demand-supply ratio of $1.11,13$ studied units have a demand-supply ratio of lower than 0.50 , and it is between 0.51-1.00 in 18 studied units. The overall demand-supply ratio of compost in northern Henan Province is approx. 0.61, lower than 1.0 and revealing an oversupply of agricultural organic waste composts. When the actual demand rate reaches $50 \%$, the ratio of the actual demand rate of composts to the supply of

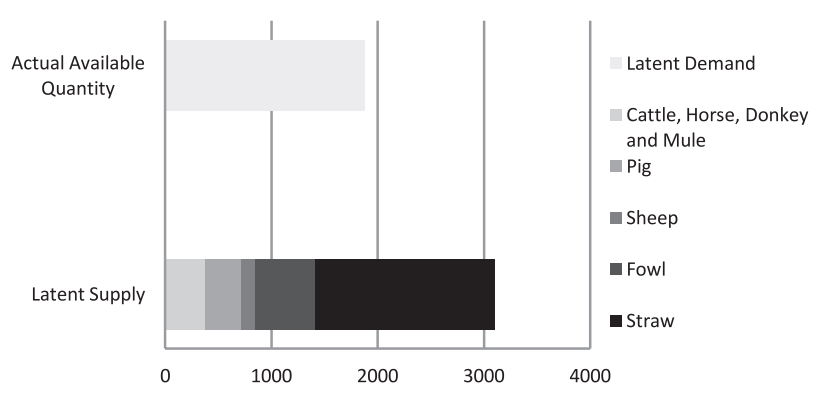

Fig. 6. Ratio of actual compost demand rate to latent supply of composts in northern Henan Province (10,000 tons/year). 
agricultural organic waste compost in northern Henan Province is shown in Fig. 6.

As shown in Fig. 6, the annual demand of compost is approx. 18.78 million tons a year in northern Henan Province, and the annual supply of livestock manure compost totals 14.1 million tons a year, accounting for $75 \%$ of actual demand. Consideration is first given to livestock manure with high nutrient content and then to straws in case of insufficient livestock manure in practical application of agricultural organic waste composts. Therefore, when the actual demand rate reaches $50 \%$, all livestock manure composts in this area can be utilized, but only a small amount of straw compost can be utilized, with 12.2295 million tons of surplus a year.

\section{Conclusions}

For more efficient utilization of agricultural organic waste compost, this research formulates the latent demand of agricultural organic waste compost and the latent supply of compost converted from agricultural organic waste in the region, and models the demandsupply balance of agricultural organic waste composts in some regions. The research assumes that agricultural organic wastes including livestock manure composts and straw composts are utilized in northern Henan Province. Objects of study include 6 urban districts, 5 county-level cities, and 21 counties of the 6 prefecture-level cities in this area. The crops' latent demand for composts and the latent supply of organic fertilizers converted from agricultural organic wastes are reckoned for a quantitative analysis of demand-supply balance, with results as follows.

1) The overall ratio of latent demand for agricultural organic waste compost to latent supply is approx. 1.21 in the studied regions of northern Henan Province, showing that demand is greater than supply. Theoretically, all agricultural organic waste can be used for agricultural production in these regions. However, there is a large deviation in the demandsupply ratio in the studied regions.

2) The sum of livestock manure compost is about $45.4 \%$ of latent supply in the studied regions of northern Henan Province, but there is a big deviation in the ratio of latent supply of livestock manure compost to that of straw compost in the six prefecture-level cities.

3) When the actual demand rate of compost is assumed to be $50 \%$ in the studied regions of northern Henan Province, the overall demand-supply ratio is approx. 0.61 , revealing an oversupply of agricultural organic waste compost in this area. Nevertheless, all livestock manure compost can be used for agricultural production in the studied regions, but straw compost is surplus in a large amount.

Apart from providing a scientific basis for the utilization of agricultural organic waste compost in the studied regions, this research also lays a solid foundation for the reduction of movement costs and the improvement of utilization efficiency in the future application of compost. As a research subject henceforth, an investigation on the expansion of limit movement area and the reduction of labor costs in the application of agricultural organic waste compost is essential for their efficient utilization.

\section{References}

1. MOURI G.R., AISAKI N.K. Using land-use management policies to reduce the environmental impacts of livestock farming. Ecological Complexity. 22, 169, 2015.

2. LIU L., KONG H.M., LU B.B, WANG J.B., XIE Y., FANG P. The use of concentrated monosodium glutamate wastewater as a conditioning agent for adjusting acidity and minimizing ammonia volatilization in livestock manure composting. Journal of Environmental Management. 161, 131, 2015.

3. SHEN X.P., CUI L.J., ZHOU D.X. Utilization of Livestock's Dejection as Biogas Origin in Building New Countryside in Heilongjiang Province-Developing Utilization of Biogas and Promoting Energy-saving and Emission Reduction. Journal of Northeast Agricultural University (English Edition). 18 (1), 91, 2011.

4. ZHOU Q.S., KITAWAKI H.T., ARAMAKI T.Y. A study on the transportation and agricultural recycling of organic wastes in Zhengzhou City, China. The 38th Symposium of Research on Environmental System of Japan Society of Civil Engineers (Japan). 38, 341, 2010.

5. YUAN M. Research on the ways and countermeasures of straw comprehensive utilization in Henan Province. Areal Research and Development. 2 (6) ,145, 2013.

6. LIN Y.,MA J., QIN F. The Structure Distribution and Prospect of China Manure Resource. ChineseAgricultural Science Bulletin. 28 (32), 4, 2012.

7. SHEN T., QIAO Y., ZHAO X.L. The status quo and problems of organic fertilizer resources utilization in Henan Province. China Earth Press \& National Agricultural Technology Spreading Center \& MOA Department of Plantation Management (jointly published). Beijing. 1-2, 2007.

8. TAKATA M.K., FUKUSHIMA K.Y., KAWAI M.K., NAGAO N.R., NIWA C.K., YOSHID T.K., TODA T.K. The choice of biological waste treatment method for urban areas in Japan - An environmental perspective. Renewable and Sustainable Energy Reviews. 23, 557, 2013.

9. Ministry of the Environment of Japan. The classification, occurrence and disposal of garbage in Japan[DB/OL]. http://www.env.go.jp/recycle/waste/conf_raw_g/01/mat03. pdf. 2011-1-13.

10. YE M.F., WU F.L., LIN D.Y. The Progress of research on composting technology of agricultural solid wastes. Energy and Environment, 6, 57, 2014.

11. YANG B.S., XIONG W.J., ZHU QIAO Y. A research on aerobic composting technology. Modern Agriculture, 7, 57, 2016.

12. YANG T.X., LI Y.J., GAO J.X., HUANG C.H., CHEN B., ZHANG L.Y., WANG X.W., ZHAO Y., XI B.D., LI X. Performance of dry anaerobic technology in the co-digestion of rural organic solid wastes in China. Energy 93, 2497, 2015. 
13. TANIKAW N.B., FURUICHI T., TOKAI A.H., ISHII K.Z ., OHTA Y.K. Factors determining use of compost in suburban areas by farmers. Waste Management Research (Japan). 17 (2), 153, 2006.

14. ARAMAKI T.Y, SUZUKI E.J., HANAKI K.S.Supply and demand analysis of compost for effective use of various organic wastes in Aichi Prefecture. Journal of Environmental Science(Japan). 14 (4), 367, 2001.

15. LI R.H., ZHOU H.F., FAN L.X., YUAN D.F. Analysis of Coupling Relationship between Farming Employee and Agricultural Planting Structure in Henan Province. Hubei Agricultural Sciences. 50 (1), 190, 2011.

16. WANG Y.L., MIAO Y.H., HAN Y.L., TAN J.F. Analyzing on utilization of agricultural resources in Henan Province. Chinese Agricultural Science Bulletin. 23 (1), 153, 2007.
17. NBS Henan Survey Team. Henan Statistical Yearbook. China Statistics Press(Beijing), 2013.

18. ZHOU Q.S. A research on the efficiency of organic waste wide-area movement - centering on the demand-supply balance in administrative region of Zhengzhou City, Henan Province, China. Doctoral Dissertation, Toyo University (Tokyo Japan). 2011.

19. BAI M.G., MA C.H. Analysis on present conditions and strategies of livestock excrement and urine pollution in Hebei province. Guangdong Agricultural Sciences. 37 (2), $162,2010$.

20. GUO Y.Q. Quantitative Appraisal of Biomass Energy of Main Crop Straw Resources and Its Geographical Distribution in Henan Province. Research of Agricultural Modernization. 34 (1), 115, 2013. 